\title{
Critical evaluation of competitiveness in international receipt of tourism amongst BRICS nations
}

\author{
Jagjit Singh, and Shikha Sharma* \\ Chandigarh University, 140413 NH-95, Ludhiana - Chandigarh State Hwy, India
}

\begin{abstract}
We are living in the world of globalization where competition is inseparable part of every business. It is possible to devolved countries to survive in this competition because of access to various economic resources. Purpose- This study focuses on one of such economic integration i.e. BRICS and has compared international Receipt of tourism among BRICS nations. This research has also appraised India's position among BRICS Nations in connection with international receipts of tourism. Research Methodology-To accomplish objectives of the research data gathering has been done form official website of Organization for Economic Cooperation and Development. A panel of data of BRICS nations from the year 2008-2019 has been built and various research tools were employed for analyzation of data. Finding- Statistics evaluation performed by utilizing the tool of ANOVA shows a statistically significant difference between the International receipts of tourism of BRICS nations. Also, apart from Brazil and South Africa, all other groupings of BRICS are displaying a statistically significant variance in terms of international receipt of tourism. Originality/Value- Data collection has been done from official website of OECD and all implications are from published research papers of authors from tourism domain.
\end{abstract}

\section{Introduction}

BRICS is a grouping acronym which refers to the developed-country countries of Brazil, Russia, India, and China at a similar stage in their economic growth. It is generally referred to as the "BRIC or as the "Big Four" Since then, the name has changed to BRICS since South Africa was added in 2010 [1].We are living in the world of globalization where competition is inseparable part of every business. It is possible to devolved countries to survive in this competition because of access to various economic resources.

On the other hand, developing nation require some patronage in this cut-throat competition. The best way supporting and growing each other country is economic integration. Many countries have done that and BRICS, SAARC, European Union, G-7, G77 are few example of this [19].Tourism is essential to the growth of many economies worldwide.

\footnotetext{
* Corresponding author: sikhasharma.uithm@cumail.in
} 
Tourism offers many advantages on host destinations. Tourism improves economic returns, generates thousands of jobs, develops a country's infrastructure, and creates a sense of civilizing interface between people and foreigners [20]. The tourism industry accounts for $5 \%$ of the global GDP. Tourism accounts for $6-7 \%$ of overall jobs. Foreign tourism is the fourth highest of global exports (after fuels, additives and automobile products). The tourism sector is worth 1 billion dollars a year [21]. This research paper will focus on comparative analysis on Total Receipts of Tourism of BRICS nations. The main objective of conducting this analysis was to observe the India position into Tourism earning in BRICS Nations. This will help us to develop an insight in comparative performance in tourism and also build an observation on scope of improvement and interventions in Tourism Industry [5].

\section{Literature Review}

For several years, the correlation between trade and industry development and visiting the attractions has been explored. This link is based on the economic assumption of tourism, whereby the concept of development driven by tourism means that tourism boost monetary expansion and other externalities [9].For the tourism-growth nexus, the time series, panel and cross-sectional data analyses were conducted. Several reports concentrate on the importance of tourism in economic development. Current research into the relationship between tourism and development is split into four strands: firstly, the theory of tourism-led development reveals that Granger tourism contributes to economic growth. For example, many studies empirically support the hypothesis of tourism-led growth, recently reported that tourism in EU countries enriches economic development. Secondly, in different state, bidirectional causality is observed between tourism and economic development [2]. Besides, the hypothesis of growth based on tourism is verified in Malta, Singapore and Turkey [10].For example, bi-directional causality among visiting the attractions and monetary growth is implied. This reaction theory is backed by many experiments in Antigua and Barbuda [3] And nine Caribbean countries [4]. Third, earlier studies discussed the hypothesis that tourism is often stimulated by economic development. Similarly supports a theory of tourism development in Tunisia. Finally, few studies have shown that tourism and economic development are not causal. In 140 developed countries no causality has been identified [6]. And the neutrality hypothesis in transition economies is verified [7].

As per UN symposium on employment and development [13], 'South-South costeffective ties are not solely or main market-driven and the scope for more constructive integration between southern states and industries exists.' Taylor (2014b) also found out that developing countries tend to have more government-led or government-led economies. While this can be valid as a general assertion, there is considerable difference between them. Although the country played a significant instruction, possession and venture role in South Africa's apartheid [8] and this inheritance is still very much visible in the country, for example through continued condition rights in the transport sector, it is now perhaps more aptly defined as a 'liberal market economy' (interview with Brazilian diplomat to South Africa, 14 August 2014, Pretoria). On the other offer, state-owned resources and building firms known as the "dragon's head" were much more influential in leading Chinese involvement on the continent. On the other hand, employees who join such firms on fixedterm contracts sometimes linger and set up their own miniature business or farms [11], resulting in Chinese involvement often changing nature in the region from big to small enterprises [12].

Tourism is really a multinational business and the biggest industry in the world. In the 21 st century, tourism is unquestionably the leading recreation activity. Worldwide, the sector hires 160 million workers and produces US\$700 billion in tax revenue." The 
majority of tourism takes place between developing countries, in the West, which implies that in the developed Western countries, countries which require the least tourism benefits, tourism is concentrated. Both emerging and industrialized countries are searching for the tourist industry because of its developmental capability [15]. Found that in 11 of the 12 poorest nations, in almost half of the low income countries and in all the lower middle income countries, tourism accounted for over 2\% of the Gross Domestic Product (GDP) [16]. Although the foreign tourism in the poor countries remains comparatively minimal, in these developing countries the influence of tourism is immense observed that the tourism industry has been growing steadily for 30 years, and as an economic market, it is robust.

The link between tourism income and economic development was very strong enough in terms of research. The role of tourism in the development of the economy is becoming significant, providing both direct and indirect jobs and foreign exchange income. The WTO and the World Travel and Tourism Council have acknowledged the clear causality between economic development and tourism income (WTTC) [17].Tried to identify the connection between tourism revenue and Pakistan's (GDP) proxy for development. The study reveals that Granger's causality and co-integration are both short-term and long-term bidirectional associations between tourism and economic development. The results indicate that economic expansion is crucial to the country's tourism growth [19, 20].

Monitor Turkey's hypothesis of tourism-led growth through the use of trimester data. In order to identify the relationship between the factors, the gross domestic product, the real exchange rate, actual net expenses and international tourist arrivals were used. The ARDL and ECM findings confirm the unidirectional long-term connection to the actual exchange rate between foreign tourism. The results show that tourism is the driving force for economic growth in Turkish and helps us reduce the country's current-account deficit. Tourism is a big factor in Spain's economic growth. They used co-integration and the causality of Granger to find a hypothesis of development driven by tourism. The results revealed that there is a long-lasting solid correlation between economic development and the rise in tourism and that the causality test offers positive evidence in favor of the hypothesis of tourist growth in the Spanish economy [14]. Report that tourism is robust in developed countries' development. In order to create the relationship between commercial expansions and tourism for Iran, the author deliberated. They used the causality of Granger and the Hsian test to assess the relationship between variables. The report reiterates the long and short-term bidirectional relationship between tourism and the country's GDP. They have a good yet marginal relationship because the revenue earned from tourism would not impact the GDP greatly.

\subsection{Objective}

1. To compare International Receipt of tourism among BRICS Nations

2. To appraise India's position among BRICS Nations in connection with International Receipts of Tourism.

\subsubsection{Hypothesis}

H0- There is no significant difference between International Receipts of Tourism among BRICS nations.

\subsubsection{Research Gap}

Various research given domains were examined and it was found that many researches have been conducted in the division of tourism and earning from the tourism. A lot of research 
paper also focused on various factors which influence tourism but none of the research has weighed the representation of BRICS nations in the context of the International Receipt of tourism. This research will contribute by assessing India's position and by giving learning's from the policy of a better performing nation amongst the economic integration.

\subsubsection{Research Methology}

To accomplish objectives of the research data gathering has been done form official website of Organization for Economic Cooperation and Development. A panel of data of BRICS nations from the year 2008-2019 has been built and various research tools were employed for analyzation of data. CAGR is additionally used to appraise the leap of different countries in tourism receipts over time. Following are the research tools used in research.

1. ANOVA

2. Mean

3. Standard Deviation

\section{Data Analysis and Results}

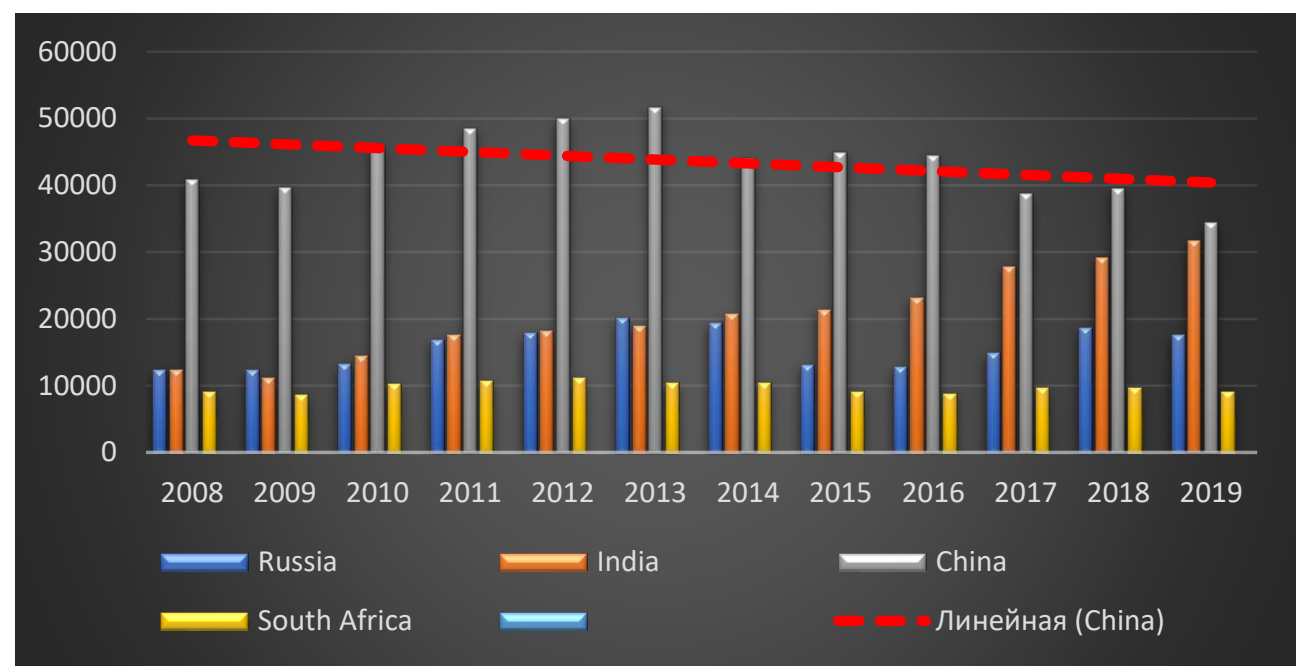

Fig. 1. International Receipts of tourism- BRICS

In Figure 1 data of international receipt of tourism concerning BRICS nations is shown. It is clear from the diagram that receipt of tourism of India is showing an upward trend. it means collection of International Receipts is increasing with time.

Table 1. Summary of Data.

\begin{tabular}{|c|c|c|c|c|c|c|c|}
\hline \multirow{7}{*}{ 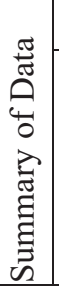 } & \multicolumn{2}{|c|}{ TABLE-1 } & $\mathrm{N}$ & $\sum \mathrm{X}$ & Mean & $\sum X 2$ & Std.Dev. \\
\hline & \multirow{6}{*}{ 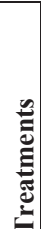 } & Brazil & 12 & 75857 & 6321.4167 & 482345755 & 506.5077 \\
\hline & & Russia & 12 & 189817 & 15818.0833 & 3099516673 & 2969.1681 \\
\hline & & India & 12 & 247283 & 20606.9167 & 5558548965 & 6486.4109 \\
\hline & & China & 12 & 522652 & 43554.3333 & 23048101408 & 5084.2179 \\
\hline & & $\begin{array}{l}\text { South- } \\
\text { Africa }\end{array}$ & 12 & 117539 & 9794.9167 & 1158846715 & 829.1291 \\
\hline & & Total & 60 & 1153148 & 19219.133 & 33347359516 & 13768.5803 \\
\hline
\end{tabular}


Table 2 Result Details

\begin{tabular}{|c|c|c|c|c|}
\hline \multirow{5}{*}{ 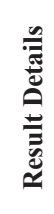 } & Source & Between-treatments & $\begin{array}{l}\text { Within- } \\
\text { treatments }\end{array}$ & Total \\
\hline & SS & 10330343973 & 854510378.3 & 11184854351 \\
\hline & $\mathrm{df}$ & 4 & 55 & 59 \\
\hline & MS & 2582585993 & 15536552.33 & \\
\hline & & $F=166.22645$ & & \\
\hline
\end{tabular}

Table 3. Pairwise Comparisons

\begin{tabular}{|c|c|c|c|}
\hline \multirow{2}{*}{\multicolumn{2}{|c|}{ Pairwise Comparisons }} & HSD. $.05=4538.3324$ & \multirow{2}{*}{$\mathrm{Q} .05=3.9885 \quad \mathrm{Q} .01=4.8380$} \\
\hline & & \multirow{3}{*}{$\begin{array}{l}\text { HSD.01 = 5504.9397 } \\
9496.67\end{array}$} & \\
\hline \multirow{2}{*}{ T1:T2 } & $\mathrm{M} 1=6321.42$ & & \multirow{2}{*}{$\mathrm{Q}=8.35(\mathrm{p}=.00000)$} \\
\hline & $\mathrm{M} 2=15818.08$ & & \\
\hline \multirow{2}{*}{ T1:T3 } & $\mathrm{M} 1=6321.42$ & \multirow{2}{*}{14285.5} & \multirow{2}{*}{$\mathrm{Q}=12.55(\mathrm{p}=.00000)$} \\
\hline & M3 $=20606.92$ & & \\
\hline \multirow{2}{*}{ T1:T4 } & $\mathrm{M} 1=6321.42$ & \multirow{2}{*}{37232.92} & \multirow{2}{*}{$\mathrm{Q}=32.72(\mathrm{p}=.00000)$} \\
\hline & $\mathrm{M} 4=43554.33$ & & \\
\hline \multirow{2}{*}{ T1:T5 } & $\mathrm{M} 1=6321.42$ & \multirow{2}{*}{3473.5} & \multirow{2}{*}{$\mathrm{Q}=3.05(\mathrm{p}=.21090)$} \\
\hline & M5 = 9794.92 & & \\
\hline \multirow{2}{*}{ T2:T3 } & $\mathrm{M} 2=15818.08$ & \multirow{2}{*}{4788.83} & \multirow{2}{*}{$\mathrm{Q}=4.21(\mathrm{p}=.03377)$} \\
\hline & M3 $=20606.92$ & & \\
\hline \multirow{2}{*}{ T2:T4 } & $\mathrm{M} 2=15818.08$ & \multirow{2}{*}{27736.25} & \multirow{2}{*}{$\mathrm{Q}=24.38(\mathrm{p}=.00000)$} \\
\hline & $\mathrm{M} 4=43554.33$ & & \\
\hline \multirow{2}{*}{ T2:T5 } & $\mathrm{M} 2=15818.08$ & \multirow{2}{*}{6023.17} & \multirow{2}{*}{$\mathrm{Q}=5.29(\mathrm{p}=.00384)$} \\
\hline & M5 $=9794.92$ & & \\
\hline \multirow{2}{*}{ T3:T4 } & M3 $=20606.92$ & \multirow{2}{*}{22947.42} & \multirow{2}{*}{$\mathrm{Q}=20.17(\mathrm{p}=.00000)$} \\
\hline & $\mathrm{M} 4=43554.33$ & & \\
\hline \multirow{2}{*}{ T3:T5 } & M3 $=20606.92$ & \multirow{2}{*}{10812} & \multirow{2}{*}{$\mathrm{Q}=9.50(\mathrm{p}=.00000)$} \\
\hline & M5 $=9794.92$ & & \\
\hline \multirow{2}{*}{ T4:T5 } & $\mathrm{M} 4=43554.33$ & \multirow{2}{*}{33759.42} & \multirow{2}{*}{$\mathrm{Q}=29.67(\mathrm{p}=.00000)$} \\
\hline & M5 $=9794.92$ & & \\
\hline
\end{tabular}




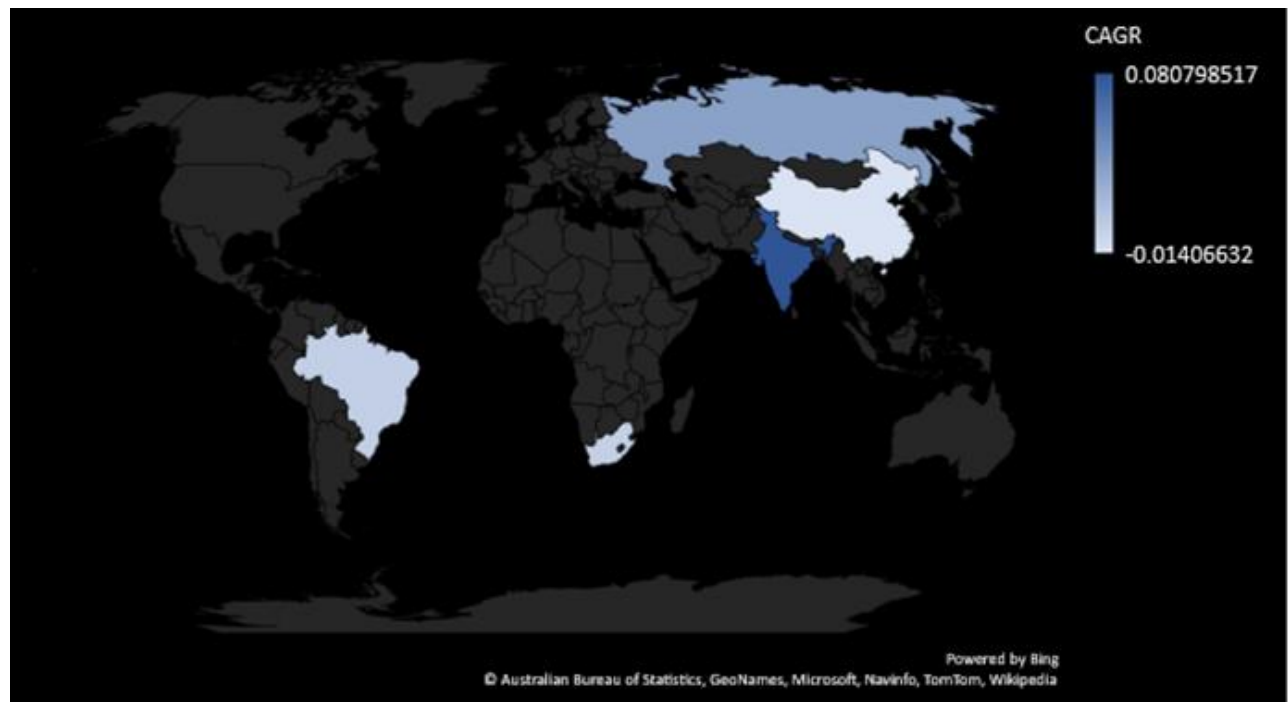

Fig. 2. CAGR of BRICS Nations

Figure 2 is clear depiction of the fact that India has performed most efficiently among BRICS nations in terms of compound annual growth rate of International Tourism Receipts. The vast nation of India has a wide range of natural and cultural wonders, as well as many tourists' attractions. Most foreigners would like to spend an unforgettable and extraordinary vacation in India. Most visitors come to India to see one or more than one tourist attractions. very well-known in the world Any of the various tourism destinations in India are well known to Indian states. There will be joys of Mother Nature, history, civilization lore, and religion, as well as natural, civil, geographic, and cultural attractions. Travelling to India is great when you get to see this stuff. India is best known for its great variety of tourism destinations in one region. The best destination for going on a honeymoon, desert safaris, special interest, honeymooning in the Sahara, and staying in India, are among the unique options India vacation possibilities [21].

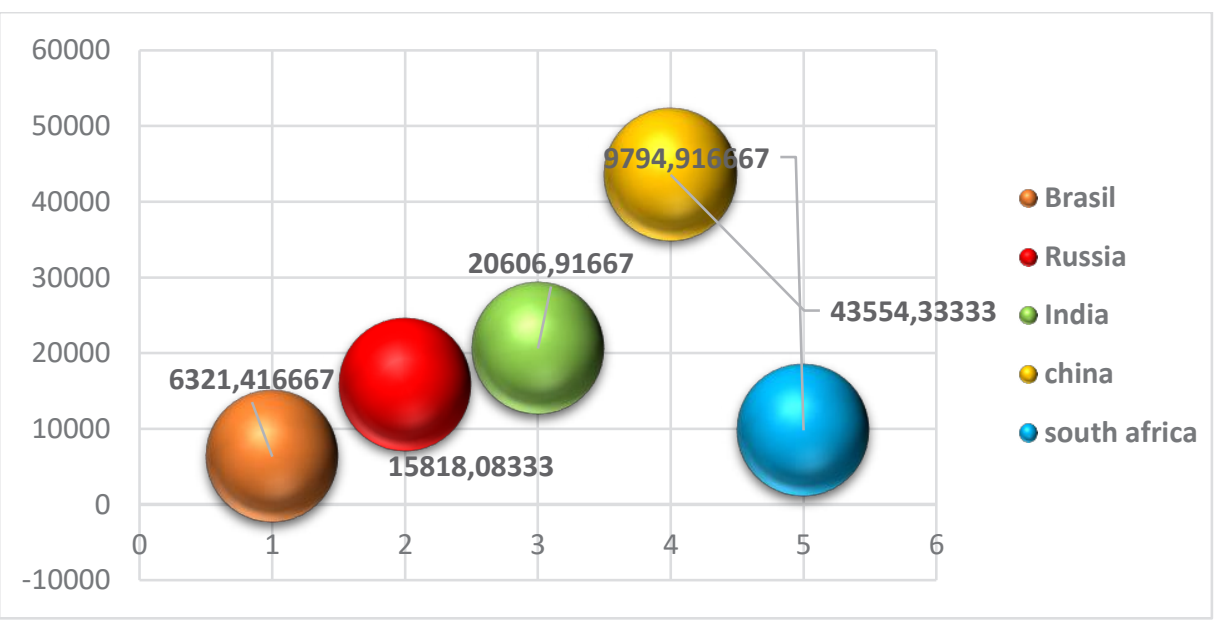

Fig. 3. Average of International receipt of tourism

In above diagram average international receipt of tourism of BRICS nation is shown. This diagram gives us a comparative analysis of the performances of various nations in the 
economic integration. It can be observed that China has best average performance in case of international receipt of tourism and Brazil has worst average performance in terms of international receipt of tourism. So in order to derive learning's from the policies this research will focus on policy implementation of China show that India may also improve its performance. In the line India standing at second number among top countries in BRICS nation. During China's efforts to establish a trade civilization, the state established policies to promote both inbound and outbound tourism as well as keeping the third in-market area centred on home. Since it was clear that the government directed business and leisure trips as well, it was no surprise when China picked out its latest approach to tourism as well. They laid the groundwork for China's tourism sector and commercial development.

\section{Results and Discussion}

ANOVA-The f-ratio value is 166.22645 . The $\mathrm{p}$-value is $<.00001$. The result is significant at $\mathrm{p}<.05$ (Table-2). Data analysis conducted by applying the tool of ANOVA shows a statistically significant difference among the International receipt of tourism of BRICS nations. Apart from Brazil and South Africa, all other combinations are showing a statistically significant variance in terms of international receipt of tourism. (Table-3).

AVERAGE- After drawing a comparison on the basis of average performances of BRICS nation in context of international receipts on account of tourism, it was found that China is amongst top countries in BRICS nation and Brazil has earned least amount of international receipts over the considered time (Table-1).

CAGR- The purpose of calculating CAGR is to observe a jump over the period of 12 years. Results of the data analyzing by employing CAGR puts India on the top and China at the bottom (Figure 2).

\section{Conclusions and Future Research}

Tourism has been an indispensable part of the reason for bringing foreign exchange to the nation. This research was conducted to analyze the receipts that countries earned because of tourism. The intention of conducting the research was to monitor the reasons that why a country is earning more than the other. This would endeavor to crack an insight that how the country can focus on earning more by tourism and would also help by revealing which nations should converge on upgrading tourism strategies to grow their revenues.

Future exploration may also consider other economic integrations such as G7, G77, European Union, SAARC etc. This would empower to cultivate further insights in the study. Same model of research by employing in other economic integration will also help in generalization of the results.

\section{References}

1. Musallam Abedtalas, Tourism and Economic Growth in Turkey: Disaggregated Approach, 6 (2017)

2. S. Katircioglu, The Singapore Economic Review (2017)

3. S. Schubert, J. Brida, W. Risso, The impacts of international tourism demand on economic growth of small economies dependent on tourism (2011)

4. N. Apergis, J. Payne, Renewable and non-renewable energy consumption-growth nexus: Evidence from a panel error correction model (2012) 
5. E. Cañada, Tourism in the geopolitics of the Mediterranean. Barcelona: Alba Sud. Contrast Reports Serie, 9 (2019)

6. E. M. Ekanayake, Aubrey E. Long, The International Journal of Business and Finance Research, 6(1), 51 (2012)

7. M. Chou, Does tourism development promote economic growth in transition countries? A panel data analysis (2013)

8. F. Rustomjee, Emergent planning for South Africa's blue economy: Evidence from coastal and marine tourism (1996)

9. P. Brazilian ambassador, The Geopolitics and Economics of BRICS' Resource and Market Access in Southern Africa: Aiding Development or Creating Dependency? (2014)

10. The BRICS' impacts on local economic development in the Global South: the cases of a tourism town and two mining provinces in Zambia (2014)

11. H. W. French, China's second continent: How a million migrants are building a new empire in Africa (2014)

12. J. Gu, Journal of Development Research, 21(4), 570 (2009)

13. A. Assadzadeh, M. H. N. Nasab, International Review of Business Research Papers, 8(2), 85 (2012)

14. Tourism-Led Growth Hypothesis: A Case Study of Pakistan (2010)

15. B. Savaş, A. Beşkaya, F. Şamiloğlu, Analyzing the impact of international tourism on economic growth in turkey (2010)

16. S. Khalil, M. K. Kakar, A. Malik, Role of Tourism in Economic Growth: Empirical Evidence from Pakistan Economy, The Pakistan Development Review, 985 (2007)

17. Of BRICs and Brains: Comparing Russia with China, India, and Other Populous Emerging Economies (2005)

18. M. Kesternich, A. Loeschel, D. Roemer, Journal of Public Economics, 137, 70 (2016)

19. G. Langford, A. Weissenberg, 2018 Travel and hospitality industry outlook. Deloitte (2018)

20. FDI, Trade, and Growth Dynamics: New Evidence from the Post-Reform India. (2011) 